\title{
Different pathogenic mechanisms of early-onset preeclampsia, late-onset preeclampsia, and hemolysis, elevated liver enzymes, low platelet syndrome
}

\section{Erken başlangıçl preeklampsi, geç başlangıçl preeklampsi ve hemoliz, yüksek karaciğer enzimleri ve düsük trombosit sayım sendromunun farklı patojenik mekanizmaları}

(1) Giovanni Sisti

Lincoln Medical and Mental Health Center, Department of Obstetrics and Gynecology, New York, United States of America

Keywords: Preeclampsia, cbc, netrophils, wbc, prediction, hellp syndrome

Anahtar Kelimeler: Preeklampsi, cbc, nötrofiller, wbc, tahmin, hellp sendromu

To the Editor,

We read with interest the article titled "First trimester complete blood cell (CBC) indices in early and late-onset preeclampsia" by Örgül et al. ${ }^{(1)}$ published in the Turkish Journal of Obstetrics and Gynecology in June 2019.

We share the same enthusiasm in the use of a cheap and simple $\mathrm{CBC}$ count as an early predictor of poor obstetric outcomes. $\mathrm{CBC}$ is the first laboratory investigation performed in every pregnant woman and its value is not limited to diagnosing current medical conditions, it can also be used as a predictor of future events.

In their article, Örgül et al. ${ }^{(1)}$ show that white blood cell (WBCs) and neutrophil counts are significantly elevated in the first trimester of pregnancies with early and late-onset preeclampsia, compared with controls. They also give an excellent clinical tool in finding a specific cut-off value, using receiver operating characteristic curve analysis; specifically, $9.55 \times 10^{3} / \mathrm{uL}$ for WBCs and $6.45 \times 10^{3} / \mathrm{uL}$ for neutrophils.

Unfortunately, in their statistical analysis, when comparing the three groups, they did not perform a post-hoc analysis to compare one group with each other.

In our recent studies, we analyzed $C B C$ indices in pregnancy affected by hemolysis, elevated liver enzymes, low platelet
(HELLP) syndrome vs. controls ${ }^{(2,3)}$. We found no differences in the first trimester in terms of neutrophil count, and we did not analyze the total WBC count. ${ }^{(2)}$ We obtained informed consent from the patients included in our study.

We think that the difference between our study and the study of Örgül et al. ${ }^{(1)}$ is due to the different pathogenesis of HELLP syndrome and preeclampsia. We think that preeclampsia is caused by an early placentation defect, whereas HELLP syndrome is determined by a maternal immunologic "storm" of circulating inflammatory molecules triggered in the third trimester.

Örgül et al. ${ }^{(1)}$ mentioned that early-onset preeclampsia was caused by early placentation defects, and late-onset preeclampsia was more related to maternal characteristics: in this regards, as mentioned earlier, a post-hoc analysis would have been very useful.

\section{Ethics}

Informed Consent: We obtained informed consent from the patients included in our study.

Peer-review: Externally peer-reviewed

Financial Disclosure: The author declared that this study received no financial support.

Address for Correspondence/Yazışma Adresi: Giovanni Sisti, MD,

Lincoln Medical and Mental Health Center, Department of Obstetrics and Gynecology, New York, United States

E-mail: gsisti83@gmail.com ORCID ID: orcid.org/0000-0003-4152-0603

Received/Geliș Tarihi: 27.08.2019 Accepted/Kabul Tarihi: 18.11.2019

${ }^{\oplus}$ Copyright 2020 by Turkish Society of Obstetrics and Gynecology

Turkish Journal of Obstetrics and Gynecology published by Galenos Publishing House 


\section{References}

1. Örgül G, Aydın Haklı D, Özten G, Fadiloğlu E, Tanacan A, Beksaç MS. First trimester complete blood cell indices in early and late onset preeclampsia. Turk J Obstet Gynecol 2019;16:112-7.

2. Sisti G, Faraci A, Silva J, Upadhyay R. Neutrophil-to-Lymphocyte Ratio, Platelet-to-Lymphocyte Ratio and Complete Blood Count
Components in the First Trimester Do Not Predict HELLP Syndrome. Medicina (Kaunas) 2019;28:55.

3. Sisti G, Faraci A, Silva J, Upadhyay R. Neutrophil-to-Lymphocyte Ratio, Platelet-to-Lymphocyte Ratio, and Routine Complete Blood Count Components in HELLP Syndrome: A Matched Case Control Study. Medicina (Kaunas) 2019;8:55. 